\title{
Unemployment and Economic Growth in Saudi Arabia 2000-2015
}

\author{
Alotaibi Mohamed Meteb ${ }^{1}$ \\ ${ }^{1}$ Department of Economics, College of Economics and Administrative Sciences, Al Imam Mohammad Ibn Saud \\ Islamic University, Saudi Arabia \\ Correspondence: Alotaibi Mohamed Meteb, Associate Prof., Department of Economics, College of Economics \\ and Administrative Sciences, Al Imam Mohammad Ibn Saud Islamic University, Saudi Arabia. \\ Received: June 25, 2017 \\ Accepted: August 3, 2017 \\ Online Published: August 10, 2017 \\ doi:10.5539/ijef.v9n9p83 \\ URL: https://doi.org/10.5539/ijef.v9n9p83
}

\begin{abstract}
The objective of this paper concentrates on determining the relationship between unemployment and economic growth in Saudi Arabia for the period 2000-2015 in order to explanation of the employment, unemployment level and its determinants to increase the employment level and avoiding the harmful effects of unemployment problems. The question to be raised is does recruitment rely on the public sector? Does the creation of job opportunities in the state's public sector have a negative or positive effect on the private sector through the effect of withdrawing its specialized technical cadres? Is the private sector growth real or illusive? Is the economic growth adequate to reduce the unemployment rate among Saudis? The results obtained show that, there are a positive relationships between the employment and real income, real investment, real government expenditure and real value of exports. On the other hand, there are negative relationships between employment and the real value of imports. The economic growth was not adequate in reducing the unemployment rate among Saudis. There is a reversal relationship between unemployment rates and the economic growth which does not effectively work in the Saudi economy. Saudis prefer to work with government sector not in private sector; Government must stimulate Saudis to work in private sector. This paper used the annual data from 2000 to 2015 for Saudi Arabia. All data in this paper was obtained from Saudi Arabian Monetary Agency (SAMA) and World Bank Development Indicator.
\end{abstract}

Keywords: employment, unemployment, saudization, economic growth, income

\section{Introduction}

The development process requirements in the kingdom of Saudi Arabia (KSA) have widened the gap between manpower supply and demand in several areas, recruitment of foreign labor, which has made force work saudization one of the fundamental challenges to the development process. Recently, the growing incompatibility between the education and training system outputs and the labor market needs have resulted in structural unemployment among Saudi citizens. Therefore, it is necessary to address the compatibility issue, in an effort to endow national human resources with the required skill levels to satisfy the labor market demands, as well as to correct the imbalances that hamper the expatriates' replacement with national labor. According to Marshall (Oxford Dictionary of Sociology, 1998), Labor force means the number of people (over 16 or the working age 16-65 years) in work and unemployment and those seeking work, as a proportion of a specified baseline population.

It was obvious since the beginning of planned development that Saudi population and work force did not satisfy all manpower related requirements of the highly and rapidly developed economy. Taking this obstacle into consideration, the early phase of development strategy was oriented towards hiring a large number of expatriates to ease the accomplishment of Saudi development objectives. Thus, one of the researchers' main areas of concern was investigating the correlation between economic growth and unemployment. For instance, studies like those of Flaig and Steiner (1989); Nickel (1986); Disney and Kiang (1990) focused on the significance of mingling the expatriates into Saudi market of labors. According to Hazledine (1981); Salter (1960), Oster (1980) and Ibrahim (2012), employment is significantly determined by the growth rate. The dynamic analysis of Saudi labor market has recently indicated that there are several factors contribute to employment. According to Nickell (1986); Darby and Wren-Lewis (1991); Pehkonen (1992), these factors include among others the overall business conditions, technical progress, prospects of the firms output, prices and level of fixed factors. Based on the findings reported by Roberts and Skoufas (1997) on how growth rate is related to employment, there was 
correlation between the individual producers' employment response and the estimates of wage elasticity. Other studies such as those of Flaig and Steiner (1989); Hazledine (1981); Disney and Kiang (1990) handled wage in order to explain the level of employment. They reported that this relation is explained based on the wage type whether nominal or real and the system of wage bargaining. In this concern, Freeman (1988) indicated that centralized and decentralized types of the system of wage bargaining lead to favourable outcomes of employment. Chletsos M. (2000) emphasized that the several sector patterns of employment trends help explain the institutional differences of wage bargaining that shape during the periods of labor excess supply the employment outcomes.

The objective of this paper concentrates on determining the relationship between unemployment and economic growth in Saudi Arabia for the period 2000-2015 in order to explanation of the employment, unemployment level and its determinants to increase the employment level and avoiding the harmful effects of unemployment problems. The question to be raised is does recruitment rely on the public sector? Does the creation of job opportunities in the state's public sector have a negative or positive effect on the private sector through the effect of withdrawing its specialized technical cadres? Is the private sector growth real or illusive? Is the economic growth adequate to reduce the unemployment rate among Saudis? This paper used the annual data from 2000 to 2015 for Saudi Arabia. All data in this paper was obtained from Saudi Arabian Monetary Agency (SAMA) and World Bank Development Indicator.

\section{Employment Structure by Economic Activities and Sex in Saudi Arabia}

Al-Humaid (2005) asserted that the Saudi labor market dilemma is a consequence of high unemployment rates spread among Saudis while massive numbers of foreign workforce were employed. In deed due to the high oil prices, the Saudi government was convinced to hire a large number of foreign workers employed basically in the private sector to help build the country's infrastructure, while Saudis were simultaneously employed in government jobs. Since the government jobs' salaries were inadequate, the government provided subsidy in the shape of flexible housing loans, free health care, and free education. Hence, Saudi citizens were endowed a comfortable middle-class lifestyle. Because of the limited government jobs which were insufficient to accommodate Saudi manpower, the government was forced to employ cheap labors in the private sector. This leads to the creation of dual labor markets, namely government jobs for Saudis and cheap foreign labor in the private sector.

The dilemma was based on imbalance while foreign labor was growing rapidly; Saudi population growth was more than $3.8 \%$ of which more than $50 \%$ were minors. This has laid huge pressure on the government creating rapid rates of in the private sector in order to cope with the annually increasingly graduated Saudis from the state-run educational and vocational institutions.

Table 1 indicates the total employment and its distribution over the economic activities in the kingdom of Saudi Arabia during the period of 2000-2015. The table shows that, the total number of the work force in the Kingdom in both government and private sectors grew from 5.71 million in 2000 to 11.68 million in 2015 at an annual growth rate of $6.9 \%$. The service sector occupies the first place of labor employment with average estimated $74 \%$, followed by the industry sector in the second place with average reached $20.5 \%$ and finally the agricultural sector comes in the third place with average estimated 5.5\%. Clearly, the agricultural sector employment dropped and its ratio in the public sector estimated in 2000 about $6.1 \%$, then decreased to almost $5.4 \%$ in 2015 . On the contrary, employment increased in the industry sector as it reached in the public sector in 2000 about $19.9 \%$, then, grown to almost $23.0 \%$ in 2015 . The employment ratio in the service sector reached $75.9 \%$ in 2008 , then, dropped to $71.6 \%$ in 2015 due to the world financial crisis which directly affected that sector compared to other sectors.

Table 1. Total employment and employment structure by economic activities in Saudi Arabia 2000-2015 (\% of total employment)

\begin{tabular}{ccccc}
\hline Year & Total Employment & Agriculture (\%) & Industry (\%) & Services (\%) \\
\hline 2000 & 5.713345 & 6.1 & 19.9 & 74 \\
2001 & 5.808615 & 6.1 & 21.1 & 72.8 \\
2002 & 5.913009 & 4.6 & 21.0 & 74.4 \\
2003 & 5.875041 & 4.5 & 20.5 & 75.0 \\
2004 & 5.411795 & 5.1 & 21.6 & 73.3 \\
2005 & 6.145564 & 5.0 & 19.8 & 75.2 \\
2006 & 6.384403 & 4.0 & 20.2 & 75.8 \\
\hline
\end{tabular}




\begin{tabular}{lllll}
\hline 2007 & 6.656841 & 4.3 & 20.8 & 74.9 \\
2008 & 7.121658 & 4.3 & 19.8 & 75.9 \\
2009 & 8.611001 & 4.1 & 20.4 & 75.5 \\
2010 & 8.965891 & 5.1 & 20.9 & 74.0 \\
2011 & 80779634 & 5.3 & 21.4 & 73.3 \\
2012 & 9.687533 & 4.7 & 23.1 & 72.2 \\
2013 & 10.884273 & 5.4 & 23.6 & 71.0 \\
2014 & 11.258741 & 5.8 & 24.0 & 70.2 \\
2015 & 11.686115 & 5.4 & 23.0 & 71.6 \\
\hline
\end{tabular}

Source: World Bank, different years.

Table 2 indicates the employment rate in the economic sectors in terms of gender during the period 2000-2015. Females' average contribution to the service sector reached about $98 \%$, almost $1.4 \%$ to the industry sector, and $0.6 \%$ to the agricultural sector, during the study period. Meanwhile, male's average contribution to the service sector estimated about $72 \%$, almost $24 \%$ to the industry sector and $5 \%$ to the agricultural sector during the study period. Clearly, the majority of females and males prefer to work in the service sector compared to other sectors besides a category of males prefer to work in the industry sector.

Table 2. Employment rate in economic activities by sex in Saudi Arabia 2000-2015 (\% of Total employment)

\begin{tabular}{lcccccc}
\hline \multirow{2}{*}{ Year } & \multicolumn{2}{c}{ Agriculture (\%) } & \multicolumn{2}{c}{ Industry $(\%)$} & \multicolumn{2}{c}{ Services (\%) } \\
\cline { 2 - 7 } & Male & Female & Male & Female & Male & Female \\
\hline 2000 & 6.7 & 2.3 & 22.8 & 1.5 & 70.5 & 96.2 \\
2001 & 6.9 & 0.9 & 24.2 & 1.3 & 68.9 & 97.8 \\
2002 & 5.3 & 0.6 & 24.0 & 1.2 & 70.7 & 98.2 \\
2003 & 4.8 & 0.5 & 22.7 & 1.4 & 71.3 & 97.5 \\
2004 & 4.6 & 0.5 & 23.9 & 1.3 & 73.4 & 98.6 \\
2005 & 5.1 & 0.4 & 22.8 & 1.2 & 72.9 & 99.3 \\
2006 & 4.6 & 0.4 & 23.4 & 1.0 & 72.0 & 98.6 \\
2007 & 4.9 & 0.4 & 24.0 & 1.4 & 71.1 & 98.2 \\
2008 & 5.0 & 0.1 & 22.7 & 1.3 & 72.3 & 98.6 \\
2009 & 4.7 & 0.2 & 23.3 & 1.5 & 72.0 & 98.3 \\
2010 & 5.2 & 0.2 & 24.6 & 1.4 & 73.4 & 99.1 \\
2011 & 4.9 & 0.1 & 25.7 & 1.2 & 75.5 & 98.7 \\
2012 & 5.2 & 0.1 & 26.1 & 1.3 & 74.6 & 98.2 \\
2013 & 5.4 & 0.2 & 26.2 & 1.4 & 75.2 & 98.1 \\
2014 & 5.1 & 0.1 & 26.4 & 1.5 & 75.9 & 98.3 \\
2015 & 5.3 & 0.1 & 26.8 & 1.2 & 75.6 & 98.7 \\
\hline
\end{tabular}

Source: World Bank, different years.

\section{Employment in the Private and Public Sectors in Saudi Arabia}

The private sector enjoys a high degree of dynamism, as evidenced by its high contribution to real GDP of about $63.6 \%$ in 2015. With its activities covering all production and services sectors and its financial and administrative capabilities enhanced, it moved from high dependence on government contracts and public expenditure to self-reliance, becoming a major partner in development. Enhanced competitiveness of the sector qualifies it to lead a larger role, particularly in view of the growth of promising investment opportunities resulting from rapid economic and social development, establishment of new economic cities, and implementation of the privatization strategy.

Table 3 indicates the private sector employment in terms of gender and nationality during the period 2005-2015. Total employees in the private sector (Saudis and non-Saudis) estimated in 2015 about 9.804421million employees compared to about 5.360000 employees in 2005 with an increased average of about $7.5 \%$ during the study period. Of the total size of the labor force (11.57 million), (34.6\%) were Saudis and $(65.4 \%)$ are expatriates. Most of these expatriates (94\%) were employed by the private sector and the remaining $6 \%$ were employed by the government sector. The participation rate of the Saudi work force in the government sector amounted to some $84.6 \%$, while the share of Saudi employment in the private sector was only $15.4 \%$ (Ministry of Planning, 2015). 
Total Saudis contribution to the force work in 2005 estimated about 620.000 employees in the private sector. Then, the number increased to 1434637 employees in 2015. Females' contribution constitutes almost $18.0 \%$ of the total Saudi force work in the private sector in 2015 compared to about 5.08\% in 2005. Non-Saudi contribution to the force work in 2005 estimated about 4740000 employees in the private sector. The figure increased to 8369784 employees in 2015 with an increased average rate of about $6.9 \%$ during the study period. Females' contribution constitutes almost $1.5 \%$ of the non-Saudi force work in the private sector in 2015 compared to about $0.17 \%$ in 2005 .

The growth rate of compound job opportunities for Saudis generally in private sector estimated from 2009-2015 about $18.5 \%$. Whereas the male growth rate at the same time was $13 \%$ the female rate estimated almost $64 \%$. This is due to the opportunity rate of Saudi women is related to legislative reform rather than economic growth. The recruitment growth rate in the private sector generally (including Saudis and non-Saudis) estimated 7.2\%. The foreign recruitment rate in the private sector was about $5.8 \%$ for males and 7.2 for females.

The majority (85.7\%) of the total workforce (Saudis and none) in the private sector were recruited in four major industries. In the construction industry, the workforce represented $36.2 \%$ of the total employment in the private sector while $26.3 \%$ are in recruited in wholesale and retail trade. Moreover, $11.7 \%$ of the total workforce is performing the community and personal services while $11.4 \%$ are working in the transportation related industries. The remaining $14.3 \%$ of the total workforce in the private sector is recruited in the agriculture industries including fishing and forestry by $7.1 \%$ and $2.3 \%$ are in transportation, storage and Telecommunications. The remaining $4.9 \%$ are divided between finance and real-estate services, electricity, gas and water industries and non-oil mining and quarrying. It is clear that the rate of Saudis' employment contribution in the private sector compared to that of the non-Saudis in the same sector estimated about $15.4 \%$ in 2015 compared to almost 13\% in 2005. It is a limited rate which indicates that Saudis' do not have the desire to work in the private sector as they prefer to work in the public sector or the government sector. Given the limited resource base of Saudi Arabia, economic growth required large imports of materials and labor. Changes in the pace and composition of economic activity were reflected in the inflow of foreign labor. Expatriate workers comprise about $70 \%$ of the Saudi labor force (Ba Ishen, 2000). Data refer to rates of Saudis recruitment stagnation in the private sector and the reduction of saudization policy effectiveness in raising the Saudis recruitment in this sector. In addition, these policies are unable to make changes in the work market structure.

Table 3. Employees in the private sector according to sex and nationality 2005-2015 (in thousand)

\begin{tabular}{|c|c|c|c|c|c|c|c|}
\hline \multirow[t]{2}{*}{ Year } & \multicolumn{2}{|c|}{ Saudis } & \multirow[t]{2}{*}{ Total } & \multicolumn{2}{|c|}{ Non-Saudis } & \multirow[t]{2}{*}{ Total } & \multirow{2}{*}{$\begin{array}{c}\text { Total } \\
\text { labor force }\end{array}$} \\
\hline & male labor force & female labor force & & male labor force & female labor force & & \\
\hline 2005 & 590000 & 30000 & 620000 & 4660000 & 80000 & 4740000 & 5.360000 \\
\hline 2006 & 673830 & 39921 & 713751 & 4782034 & 4782034 & 4866989 & 5.580740 \\
\hline 2007 & 714565 & 51056 & 765621 & 4964241 & 96994 & 5061235 & 5.826856 \\
\hline 2008 & 777606 & 51451 & 829057 & 5301290 & 91600 & 5392890 & 6.221947 \\
\hline 2009 & 633075 & 48406 & 681481 & 6125028 & 89039 & 6214067 & 6.895548 \\
\hline 2010 & 669037 & 55618 & 724655 & 6178130 & 88415 & 6266545 & 6.991200 \\
\hline 2011 & 744990 & 99486 & 844476 & 6823554 & 113466 & 6937020 & 7.781496 \\
\hline 2012 & 918793 & 215840 & 1134633 & 7244206 & 108694 & 7352900 & 8.487533 \\
\hline 2013 & 960241 & 228419 & 1188660 & 7999536 & 121820 & 8121356 & 9.310016 \\
\hline 2014 & 980536 & 253112 & 1233648 & 8131849 & 124574 & 8256423 & 9.490071 \\
\hline 2015 & 1175843 & 258794 & 1434637 & 8244419 & 125365 & 8369784 & 9.804421 \\
\hline
\end{tabular}

Source: Saudi Arabian Monetary Agency, different years.

Table 4 shows the public sector employment in terms of gender and nationality during the study period of 2000-2015. Total Saudis and non-Saudis employment in the public sector in 2015 reached about 1111818 million employees compared to almost 694770 thousand employees in 2000 with increased average rate of about $4.0 \%$ during the study period. The rate of Saudis working in the state and affiliated to the Civil Service Ministry about $20 \%$ only of the total Saudi force work. Total Saudis contribution to the force work in the public sector in 2000 estimated about 613322 thousand employees. Then, the figure increased to 957160 million employees in 2015 with increased average of about $3.7 \%$ during the study period. Females' contribution to total Saudi force work in the public sector constitutes almost $40.4 \%$ in 2015 compared to about $33.4 \%$ in 2000 . The non-Saudis contribution to the public sector force work in 2000 estimated about 81448 thousand employees. The figure decreased to about 64658 thousand employees in 2015 with a decreased average rate of almost $1.4 \%$ during the 
study period. It is clear that the non-Saudis' contribution to total public sector force work was limited as it estimated in 2015 about $7 \%$ compared to almost $11.7 \%$ in 2000. The drop is attributed to the saudization trend and Saudi local labor replacement to that of the foreign labors.

According to the data, recruitment opportunities grew in both public and private sectors. Recruitment opportunities increased in the public sector due to the creation of 300 thousand jobs in 2015. This is attributed to the fact that the state's circles were restructured and temporary labors were transformed into permanent status. In addition, the formation of new ministries like the population ministry and anti-corruption corporation creates new jobs recruitment in such ministries. This happens after a period of government spending long rationalization fearing that creation government opportunities would badly affect the growth of job opportunities at the private sector. This should have occurred if there was a competition between state job opportunities and their private sector counterparts as in the field of teaching because the graduates prefer to work in the public sector rather than in the private sector.

Table 4. Employees in the public sector according to sex and nationality 2000-2015 (in thousand)

\begin{tabular}{cccccc}
\hline & \multicolumn{2}{c}{ Saudis } & \multicolumn{2}{c}{ Non-Saudis } & Total \\
\cline { 2 - 5 } Year & male labor force & female labor force & male labor force & female labor force & labor force \\
\hline 2000 & 408640 & 204682 & 45776 & 35672 & 694770 \\
2001 & 416803 & 214221 & 45644 & 34191 & 710859 \\
2002 & 438023 & 214912 & 43400 & 31653 & 727988 \\
2003 & 452555 & 224965 & 41698 & 27748 & 746966 \\
2004 & 463487 & 231007 & 41342 & 27429 & 763265 \\
2005 & 472727 & 240108 & 41436 & 29005 & 783276 \\
2006 & 490109 & 243757 & 39779 & 30018 & 803663 \\
2007 & 508006 & 252989 & 36851 & 32139 & 829985 \\
2008 & 552718 & 275128 & 35807 & 36058 & 899711 \\
2009 & 583989 & 282785 & 36202 & 38924 & 941900 \\
2010 & 589627 & 295088 & 33677 & 41441 & 959833 \\
2011 & 616748 & 302360 & 37128 & 41902 & 998138 \\
2012 & 643212 & 369840 & 36663 & 39786 & 1089501 \\
2013 & 650215 & 371254 & 35259 & 34568 & 1091296 \\
2014 & 654328 & 372698 & 34687 & 32987 & 1094700 \\
2015 & 659748 & 387412 & 32784 & 31874 & 1111818 \\
\hline
\end{tabular}

Source: Saudi Arabian Monetary Agency, different years.

Table 5 indicates the employees' monthly average wages in the private sector during the period of 2000-2015. Females' average wage rose from 1795.3SR in 2005 to 2430.7 SR in 2015 with an increased average of about 3.6\%. Males' average wages rose from 1350.4 SR in 2005 to 2940.7 in 2015 with an increased average of about $11.7 \%$ during the study period. The Saudis wage average growth rate estimated about $7.3 \%$ as a compound rate in the private sector. This refers to Saudization in the private sector was a real as the Saudis wages rate rose from 3145.7 SR in 2005 to 5371.4 SR in 2015. It is clear that wages have remarkably increased since the beginning of 2011 as a reaction to the revolutions occurred in the Arab spring countries. Total average of wage growth rate estimated in 2011 about $57.6 \%$ the reduced to $2.0 \%$ in 2015 . The wages average is still relatively reduced but it improves a year after another. This evidences that the growth was not illusive and the recruitment growth in the public sector was positive and interacted with a parallel growth in the private sector. However, foreigner's wages average is still less than 1500 SR. this refers that most of them are service labors and constitute high majority compared to the Saudis in the private sector whose rate does not exceed $14 \%$.

Table 5. Average monthly wages of employees in the private sector 2005-2015 (SR)

\begin{tabular}{|c|c|c|c|c|c|c|}
\hline \multirow[t]{2}{*}{ Year } & \multicolumn{2}{|c|}{ Average wages according to sex } & \multirow[t]{2}{*}{ Total } & \multicolumn{2}{|c|}{ The growth rate of average wages } & \multirow[t]{2}{*}{ Total } \\
\hline & male & female & & male & female & \\
\hline 2005 & 1350.4 & 1795.3 & 3145.7 & -1.9 & -3 & -1.9 \\
\hline 2006 & 1373.1 & 1883.8 & 3256.9 & 1.7 & 4.9 & 3.5 \\
\hline 2007 & 1342.6 & 1810.2 & 3152.8 & -2.2 & -3.9 & -3.2 \\
\hline 2008 & 1340.9 & 1880.6 & 3221.5 & -0.1 & 3.9 & 2.2 \\
\hline
\end{tabular}




\begin{tabular}{lcccccc}
\hline 2009 & 966.7 & 1604.7 & 2571.4 & -27.9 & -14.7 & -20.2 \\
2010 & 1278.7 & 1972.8 & 3251.5 & 32.3 & 22.9 & 26.4 \\
2011 & 2391.2 & 2733.4 & 5124.6 & 87.0 & 38.5 & 57.6 \\
2012 & 2613.9 & 2187.3 & 4801.2 & 9.3 & -19.9 & -6.3 \\
2013 & 2850.3 & 2250.7 & 5101.0 & 9.0 & 2.9 & 6.2 \\
2014 & 2920.4 & 2340.8 & 5261.2 & 2.4 & 4.0 & 3.1 \\
2015 & 2940.7 & 2430.7 & 5371.4 & 0.7 & 3.8 & 2.0 \\
\hline
\end{tabular}

Source: Saudi Arabian Monetary Agency, different years.

\section{Unemployment in Saudi Arabia}

The findings of the 8th Development Plan describe unemployment in the kingdom as a 'structural unemployment'. The description is based on the discrepancy between manpower supply and demand in regards of both quality and quantity. The discrepancy between labor market supply and demand and absence of attraction to work in the private sector jobs is attributed in part to low wages compared to the public sector and in essence to 'skills imbalance'. According to the Ministry of planning report (2009), Saudi job seekers do not possess the skills desired by the private sector. Saudi unemployment comprises 629 Saudis of them $12 \%$ are able to work and $5.7 \%$ of the total force work if foreign workers are counted.

Table 6 shows the KSA unemployment rate during the period 2000-2015 where the total unemployment rate (Saudis and foreigners) witnessed an increase estimated $4.5 \%$ in 2000 to $5.6 \%$ in 2015. Saudis outnumbered their foreign counterparts in the unemployment rate. Consequently, the Saudis' low employment of Saudis in the private sector led to an increased unemployment rate ranging from $8.15 \%$ in 2000 to $11.5 \%$ in 2015 . On the contrary, the unemployment rate decreased among foreign labors from 0.84 in 2000 to $0.72 \%$ in 2015 . This poses two very important questions: Is the Saudi high unemployment rate mainly attributed to the existence of many professions in which Saudis do not accept to work? Government sector and not the private sector is the main preference of Saudis to work. Foreigners low unemployment rates prove the high demand laid on them and the shortage of their domestic supply. This is due to both economic growth characteristics and structures either in the kingdom and the Gulf States which focused on the low wages sectors preferring to hire low wages foreign labors. The Saudi unemployment increased rate is due to their preference to work at the government sector instead of the private one as opposed to the foreign labors. As to the second important question: Is the economic growth rate inadequate to accommodate to the newcomers to the Saudi labor market? Therefore, the economic growth rate should be reinforced to accommodate the newcomers to the labor market in the KSA.

Table 6. Total employment and unemployment rate 2000-2015 (thousands of workers)

\begin{tabular}{ccccc}
\hline Year & Total Employment & \multicolumn{2}{c}{ Unemployment Rate } & Total Unemployment \\
& & Saudis & Non-Saudis & 4.57 \\
\cline { 3 - 4 } 2000 & 5.713345 & 8.15 & 0.84 & 4.62 \\
2001 & 5.808615 & 8.34 & 1.11 & 5.27 \\
2002 & 5.913009 & 9.66 & 0.93 & 5.56 \\
2003 & 5.875041 & 10.35 & 0.79 & 5.82 \\
2004 & 5.411795 & 11.00 & 0.79 & 6.10 \\
2005 & 6.145564 & 11.52 & 0.80 & 6.30 \\
2006 & 6.384403 & 12.00 & 0.80 & 5.60 \\
2007 & 6.656841 & 11.00 & 0.40 & 5.00 \\
2008 & 7.121658 & 9.81 & 0.40 & 5.40 \\
2009 & 8.611001 & 10.51 & 0.30 & 5.73 \\
2010 & 8.965891 & 11.62 & 0.38 & 6.41 \\
2011 & 8.779634 & 12.42 & 0.40 & 6.52 \\
2012 & 9.687533 & 12.12 & 0.59 & 5.36 \\
2013 & 10.884273 & 11.12 & 0.42 & 5.41 \\
2014 & 11.258741 & 11.63 & 0.65 & 5.61 \\
\hline
\end{tabular}

Source: Saudi Arabian Monetary Agency, different years.

Table 7 indicates the unemployment rate in Saudi Arabia in terms of gender during the period 2000-2015. The unemployment rate increased among females compared to males. Females' unemployment rate estimate in 2000 
about $9.3 \%$, then increased to $23.5 \%$ in 2015 . Meanwhile males' unemployment rate decreased from $3.8 \%$ in 2000 to $3.6 \%$ in 2015 . The increase of females' unemployment increase is attributed to reasons related to traditions and customs of the work nature and other legislative reasons that prohibit women's work in certain sectors.

Table 7. Unemployment rate in Saudi Arabia 2000-2015 (\% of Labor Force)

\begin{tabular}{cccc}
\hline Year & \% of female labor force & \% of male labor force & \% of total labor force \\
\hline 2000 & 9.3 & 3.8 & 4.5 \\
2001 & 9.1 & 3.9 & 4.6 \\
2002 & 11.5 & 4.2 & 5.2 \\
2003 & 12.8 & 3.8 & 5.5 \\
2004 & 13.7 & 4.1 & 5.8 \\
2005 & 14.2 & 4.5 & 6.1 \\
2006 & 14.0 & 4.7 & 6.3 \\
2007 & 13.2 & 4.2 & 5.6 \\
2008 & 13.0 & 3.5 & 5.0 \\
2009 & 15.9 & 3.5 & 5.4 \\
2010 & 16.2 & 3.4 & 5.7 \\
2011 & 19.2 & 3.3 & 6.4 \\
2012 & 21.3 & 2.7 & 6.5 \\
2013 & 21.4 & 3.7 & 5.3 \\
2014 & 22.1 & 3.8 & 5.4 \\
2015 & 23.5 & 3.6 & 5.6 \\
\hline
\end{tabular}

Source: World Bank indicator, different years.

Al-Shammary et al. (2007) have investigated the supply and demand discrepancy existed in the labor market over a period of successive five years starting from 2000 till 2005. The researchers compared a number of graduates from state-run educational and training institutions, their fields of study to a number of foreigners recruited in classified positions in the labor market. The researchers reported four main categories of supply and demand to those positions based on the required period for the fulfillment of their ample saudization in condition that the average of the graduate numbers or their supply remains fixed for the above-mentioned five years. The first category comprises positions in the Saudi labor market where there is a surplus of Saudi graduates over market demand particularly from the fields of study of literature and teaching. The second category includes positions which require 5 to 20 years of Saudi graduates current supply merely to meet the existent demands. For instance, such positions include medical doctors, engineers, technicians in all technical areas along with computer and electronic specialists. The third category includes positions which require more than 20 years of current graduates supply to meet the existent market demands. For instance, such positions comprise laboratories and medical supporting technicians, automobile mechanics and electricians. This attributed to the lack of majors in government educational and training institutions veterinary doctors, salespeople, and construction technicians. The fourth category includes positions which require only short focus training courses or merely on-the-job training to be held by Saudis possessing skills for these positions. For instance these positions include managerial skills at various industrial sectors, aviation specialists, pilots, human resource and insurance specialists.

Several studies such as those of Ghaban et al. (2002), Al-Nowaiser (2001), and Ba Ishen (2002) have handled unemployment in the KSASaudi Arabia. They reported the following findings. Saudi Arabia differs in its unemployment from the other Arab countries because the Saudi labor market subjects to change based on the oil prices fluctuation as they are the main economic source of the KSA. Unemployment rates are equally high among both uneducated and educated Saudis regardless of their fields of study which do not fulfill the skills demand by the labor market. Unemployment rates prevail throughout the KSA either in cities or villages or among males or females. However, the latter rates are significantly higher estimated 35\% of females aged 20-24 years and 16\% for females aged 25-29 years. Unemployment rates are higher among university graduates majoring in literature compared to those graduates majoring in scientific fields. Being rigorous, the foreign labor force always competes with Saudi labor force on available jobs in the labor market to the extent of exceeding its demands in certain positions. The foreign labor force is mostly constituted of unskilled workers who are considered as the main source of behind the Saudis unemployment. Unemployment basically arises from the 
dependence of the private sector organizations and their preference to hire foreign labors instead of Saudi because of several reasons like it is more cheaper and thus profitable for the private sector to recruit them rather than Saudis who need more training. The concealment of business ownership and the sponsorship system exploitation lead to the unemployment rates increase. According to Ministry of Planning (2008) the period of Sixth Development Plan has witnessed the growing phenomenon of concealing the businesses true ownership which legally conceals the foreigners' identity in order to enable them undertake some business activities and delimit as well Saudis' employment opportunities in the private sector. Obviously, unemployment in the KSA country is a direct result of discrepancy between education outcomes and labor market demands at the secondary and university levels. There are fundamental differences between job description in both government and private sectors with less incorporation to most recent changes of such jobs in the labor market. Significant imbalanced employment differences between the recruitment of both public and private sectors affects the attractiveness of Saudis to join the private sector jobs. There is an absence of any type of government social security system to support unemployed Saudis although they are able and willing to work. These employment differences include as well long working hours, unobvious promotion system, absence of job security, few vacations, and lack of formal retirement plan particularly for small enterprises which recruit 10 or less employees.

Several studies like those of Al-Sheikh (2001), (Ba Ishen, 2002); Al-Nowaiser (2001); Al-Sultan (1998) have explained why the private sector employers prefer to recruit foreigners instead of the Saudi nationals. First, Employers are of the opinions that Saudi qualifications do not satisfy the required skills by the private sector. Thus, they look for qualified and highly trained labor at low costs among the foreigners. Second, they controversially claim that higher education institutions in the KSA do not provide graduates in the areas of specialization which the private sector requires. They believe that graduates of theoretical and literary fields of study exceed graduates from scientific and technical disciplines. Furthermore, private sector employers believe that Saudi youth are reckless and dependent due to the financial boom emerged in the early seventies. Along with absence of work education discipline, this culture has resulted in less observation of the private sector employment regulations on the part of Saudi employers due to its challenging working conditions. In addition, based on the findings reported by Al-Sheikh the employers believe that job seekers among the Saudis do not have the experience and aspiration necessary for high productivity working environment which are deemed essential to this sector. Most job seekers among the Saudis lack communication skills particularly in English which is considered as an essential requirement by employers in spite of Ghaban's et al. (2002) argument that some of these jobs do not require good command in English. Employers claim as well that Saudis seek managerial and administrative jobs and are reluctant and unwilling to relocate their jobs from one city to another. Lastly, employers encounter the dilemma resulted from the imbalanced labor regulations in the KSA. According to (Alzalabani, 2003), it is difficult on the one hand to retrench Saudis while they are not stable on the other in their private sector jobs because of competitors head hunting. Due to such reasons, it is obvious that the highest priority is given to incompatibility of training and education outcomes of Saudis who satisfy the market skills demand. Controversially, high skills are the causes for the other reasons in an agreement with the widely accepted perspective that of Saudis evade the private sector employment.

Unemployment is a subsequence of certain negative economic, social and security outcomes which resulted from the existence of foreign work force in the KSA. In addition, they can affects as well the labor market. These outcomes comprise among other things the following points. Many foreign workers are recruited in jobs different from the ones registered in their work permits. Some of the unneeded groups in the labor market transfer their sponsorships. These processes provide foreign workers with a legal stay in the KSA to search for alternative jobs. The arrangements of Family reunion lay heavy burden on services like education and health, the remits annual increase rate of $9.5 \%$ as foreign workers transfer money to their home countries constituting $11.79 \%$ of the country's GDP over the last decade 1990-2015. The foreign labor force constitutes a high proportion of the Saudi population estimated $46 \%$.

\section{Economic Growth and Unemployment in Saudi Arabia}

During the 2005-2015 periods, the Saudi economic growth rate exceeds that of the population growth where the nominal domestic product reached roughly $11.6 \%$ and the real one estimated almost 5\%. Meanwhile, the population growth comprising foreigners estimated almost 3.2\% where Saudi growth reached $2.3 \%$ and foreigner growth estimated $6.5 \%$. The population growth does not exceed the nominal and real economic growth. In the KSA, the high economic growth rates lead to recruiting labors from different countries. This indicates the positive effect resulted from the high Saudi economic growth on the world economic growth, especially the neighboring states from which the KSA recruits a large number of labors The KSA flexible employment system helps further continuation of both recruitment and bringing in the foreign labors. Data of the KSA economic 
growth data, recruitment and unemployment indicate the upward economic growth success in concurrently providing several job opportunities for Saudi and foreign labors.

Data of Table 8 indicate the increase of gross domestic product from 623.2189 billion SR in 2000 to 1648.8302 billion SR in 2015 with an annual increase rate of $11.0 \%$. This is attributed to the annual exports increase by 9.8.1\%. The exports value increased from 309.6 billion SR in 2000 to about 763.3 billion SR in 2015 . Consequently, it has led to the recruitment rate increase; a matter which refers to a positive relationship between exports increase and recruitment rates on the contrary to the imports increase which leads to unemployment increase. The imports value increased from 176.6 billion SR in 2000 to 655.03 billion SR in 2015 with an annual increase rate estimated $18.1 \%$. In addition, capital formation leads to recruitment size increase as the capital formation increased from 123.8 billion SR in 2000 to 697.5 billion SR in 2015 with an annual increase estimated $31.1 \%$. The government consumption contributes to recruitment size increase as the government size increased from 49.2 billion SR in 2000 to 157.8 billion SR in 2015 with an annual increase of $14.7 \%$.

Table 8. Total employment and economic variables in Saudi Arabia (2000-2015)

\begin{tabular}{|c|c|c|c|c|c|c|}
\hline Year & $\begin{array}{l}\text { Number of } \\
\text { Employees } \\
\text { (L) } \\
\text { (Million) } \\
\end{array}$ & $\begin{array}{c}\text { Real Gross Domestic } \\
\text { Product (RGDP) } \\
(1999=100) \\
\text { (Billion Riyal) }\end{array}$ & $\begin{array}{c}\text { Real Gross Capital } \\
\text { Formation (RI) } \\
(1999=100) \\
\text { (Billion Riyal) }\end{array}$ & $\begin{array}{c}\text { Real Value of } \\
\text { Exports (RX) } \\
(1999=100) \\
\text { (Billion Riyal) }\end{array}$ & $\begin{array}{c}\text { Real Value of } \\
\text { Imports (RM) } \\
(1999=100) \\
\text { (Billion Riyal) }\end{array}$ & $\begin{array}{c}\text { Real Government } \\
\text { Consumption RGC } \\
(1999=100) \\
\text { (Billion Riyal) }\end{array}$ \\
\hline 2000 & 5.713346 & 623.2180 & 123.8095 & 309.6875 & 176.6658 & 49.20737 \\
\hline 2001 & 5.808615 & 629.2625 & 126.9663 & 275.5682 & 166.3607 & 50.66638 \\
\hline 2002 & 5.913009 & 629.7750 & 130.6273 & 296.9781 & 171.4763 & 50.18862 \\
\hline 2003 & 5.875041 & 678.1551 & 152.7401 & 382.7197 & 200.1211 & 54.49571 \\
\hline 2004 & 5.411795 & 713.9152 & 163.0644 & 515.6632 & 253.7714 & 61.68671 \\
\hline 2005 & 6.145564 & 753.5182 & 203.6149 & 749.2816 & 342.0934 & 72.95520 \\
\hline 2006 & 6.384403 & 777.2304 & 241.1017 & 873.6434 & 439.6945 & 85.93029 \\
\hline 2007 & 6.656841 & 802.9888 & 301.5075 & 963.6071 & 561.4992 & 88.62906 \\
\hline 2008 & 7.121658 & 839.0202 & 357.8090 & 1239.873 & 678.5355 & 95.45671 \\
\hline 2009 & 8.611001 & 836.9214 & 360.9001 & 697.3894 & 358.3217 & 94.8829 \\
\hline 2010 & 8.965891 & 871.3256 & 383.9992 & 922.3214 & 400.7123 & 103.9590 \\
\hline 2011 & 8.779634 & 1158.5213 & 388.4962 & 1343.216 & 493.3658 & 116.9823 \\
\hline 2012 & 9.687533 & 1217.9123 & 392.5741 & 1428.712 & 583.5213 & 129.1772 \\
\hline 2013 & 10.884273 & 1318.3573 & 662.4355 & 1409.523 & 630.5822 & 132.2548 \\
\hline 2014 & 11.258741 & 1516.8496 & 714.2353 & 1284.122 & 651.8726 & 149.6598 \\
\hline 2015 & 11.686115 & 1648.8302 & 697.5327 & 763.313 & 655.0353 & 157.8741 \\
\hline
\end{tabular}

Source: Saudi Arabian Monetary Agency (2015) and World Bank indicator, different years.

Essentially, the economic growth is related to the economic development which results in creating wealth and production and subsequently increases the exports increase. In turn, exports increase varies the economic growth of income resource rather than being only restricted to the yield income of oil. There is a strong correlation between exports and economic growth. Based on the Trade Neoclassical Theory, exports are viewed as the economic growth stimuli via the optimal distribution of the economic resources which in turn improves production efficiency. Jung and Marshall (1985) explained that accumulation of capital results in the increase of exports size because of the advanced technology. However, the economic growth based on yield income does not support exports since it is not oriented to the development of other economic sectors. Those economic sectors increase productivity and develop exports along with oil exports. Meanwhile they focus on the most economic sectors able to ensure the economic growth increase and stability in the KSA.

The inadequacy of economic growth was apparent in the reduction of unemployment rate among Saudis. Indeed, the economic growth does not have direct effects to reduce the unemployment rates, but reduces unemployment by providing further through jobs in the economy. In most cases, the high economic growth rates could be a sequence of the growth in sectors recruiting a small number of labors because of its high capital intensity. This happens in the petrochemical sector with its several times doubled capacity of productivity, but it only hires a limited number of labors. The economic growth data and recruitment indicate a roughly positive interrelation between the GDP real growth of the non-oil sector and the recruitment levels in general. The high economic growth rates, distinguished the oil sector, have limited effects on recruitment because of the reliance of this sector on capital. The oil sector recruitment constitutes less than $1 \%$ of the total labor in the KAS. The high 
economic growth mainly exists in the sectors of construction sectors and some service sectors which totally depend on hiring foreign labors. As such the benefit of Saudis having employment in these sectors is limited. There is a reversal interrelation between unemployment rates and the economic growth which does not have effective impacts on the Saudi economy. The reasons include the concentration of economic growth in certain sectors like labors recruitment, low-wage sectors, the high growth rates of national labor size especially youth and women, the openness of Saudi work market to recruit foreign labors in addition to various work markets and foreign and national labors. Therefore, it is difficult to establish relations which comprise all work markets in the KSA.

\section{Conclusion and Implications}

The present paper aimed to explain the relationship between unemployment and economic growth in the KSA during the 2000-2015 periods. Findings indicated that there are positive relationships between the employment and real income, real investment, real government expenditure and real value of exports. However, negative relationships were found between employment and the real value of imports. It is the government sectors not the private ones which represent the preference of Saudis choice to work in. The increase of economic growth rates in the KSA does not indicate the employment growth rates as opposed to the claim of OKUN Law that shows the relationship between the economic growth and the unemployment change rate. He views unemployment as a decreased rate in relation to the rates of economic growth. In the KSA, the growth-sustain oriented economic policies help increase growth without the necessity of reducing the unemployment rate. Furthermore, most investments are concentrated on the oil sector because it is considered as which is considered as the engine of Saudi economic economy and interprets most of the realized growth. Government should provide incentives to encourage Saudis to work in private sector. Consequently, the government should encourage the private sector to recruit Saudis whether through creating new job opportunities or replacing Saudis for foreign employees. The services sectors mostly recruit female employees while the services and industrial sectors mostly recruit male employees. In the KSA, employment levels in agriculture sector are very limited for both males and females, in spite of the fact that it recruits more males than females. In addition, government should encourage employers to increase female recruitment in the industrial and promotion sectors to make Saudis accept some socially under-evaluated jobs.

\section{References}

Al-Humaid, A. (2005). Saudization or the Deluge. King Fahad National Library: Riyadh, Kingdom of Saudi Arabia. Retrieved from https://books.google.com.eg/books?isbn=0081008988

Al-Nowaiser, K. (2001). Unemployment of Saudi Higher Education Institutions Graduates: Their realities, reasons and solutions. Unpublished $\mathrm{PhD}$ thesis, Umm Al-Qura University, Makkah, Kingdom of Saudi Arabia.

Al-Shammary, A., \& Al-Dikheelallah, K. (2007). Obstacles to Saudize Jobs in the Private Sector. A paper submitted to the 13th Annual Forum of Saudi Economic Association, 17-19/10/2008. Riyadh, Kingdom of Saudi Arabia.

Al-Sheikh, A. (2001). Evaluation of the Applicability of Selected Human Resources Management Concepts within the Context of Saudi Arabia. Unpublished Ph.D. Thesis, University of Burnel, UK.

Al-Sultan, A. (1998). Saudization of Labour Market in The Kingdom of Saudi Arabia: Dimensions, obstacles and proposed solutions. Institute of Public Administration, 38(3), 471-494. Retrieved from https://link.springer.com/chapter/10.1007/978-1-4419-5987-4_12/

Alzalabani, A. (2003). International briefing 11: Training and Development in Saudi Arabia. International Journal of Training and Development, 6(2), 125-140. https://doi.org/10.1111/1468-2419.00154

Ba Ishen, A. (2002). Influences of Foreign Labour on the Kingdom of Saudi Arabia. Unpublished PhD thesis, Institute of Arabic Research and Studies, League of Arab States: Cairo, Egypt.

Chletsos, M., Kollias, Ch., \& Manolas, G. (2000). The relationship between wages, productivity and labour demand in Greece: An error correction approach. RISEC, 47(1), 95-110.

Darby, J., \& Wren-Lewis, S. (1991). Trends in labor productivity in U.K. manufacturing. Oxford Economic Papers, 43(3), 424-442. https://doi.org/10.1093/oxfordjournals.oep.a042009

Disney, R., \& Kiang, H. S. (1990). Do real wages matter in an open economy? The case of Singapore 19661987. Oxford Economic Papers, 42(3), 635-657. https://doi.org/10.1093/oxfordjournals.oep.a041968

Flaig, G., \& Steiner, V. (1989). Stability and dynamic properties of labour demand in West German 
manufacturing. Oxford Bulletin of Economics and Statistics, 51(4), $395-412$. http://dx.doi.org/10.1111/j.1468-0084.1989.mp51004003

Freeman, R. B. (1988). Evaluating the European view that the United States has no unemployment problem. American Economic Review, 78(2), 294-99.

Ghaban, M. et al. (2002). Unemployment: Reasons and Remedies. Ministry of Interior, Madina Emirate: Madina, Kingdom of Saudi Arabia.

Hazledine, T. (1981). Employment functions and the demand for labour in the short run. In Z. Hornstein, J. Grice, \& A. Webb (Eds.), The Economics of the Labour Market. HMSO: London, UK.

Ibrahim, M. (2012). The determinants of private sector demand for employment in Egypt: 1990-2007. International Symposium on Business, Economics and Financial Applications (ISBEFA), June 1-2, Kefalonia, Greece, pp. 195-208.

Jung, W., Peyton. J., \& Marahall, P. J. (1985). Export Growth and Causality in Developing Countries. Journal of Development Economics, 18, 1-13. https://doi.org/10.1016/0304-3878(85)90002-1

Ministry of Labour and Social Affairs. (2013). Labour Market in the Kingdom of Saudi Arabia a Generation from Now. A Paper Presented in the Future Vision for the Saudi Economy Symposium. Riyadh, Kingdom of Saudi Arabia: Ministry of Planning Press.

Ministry of Planning. (2008-2015). Human Development Report. Riyadh: Ministry of Planning Press.

Mohammed, A. A. (2012). Labor Demand and Economic Growth in Saudi Arabia. American Journal of Business and Management, 1(4), 271-277.

Nickel, S. (1986). Dynamic models of labor demand. In Ashenfelter, \& R. Layard (Eds.), Handbook of labor economics. New York: Elsevier.

Oster, G. (1980). Labour relations and demand relations: A Case study of the unemployment effect. Cambridge Journal of Economics, 4(4), 337-348.

Pehkonen, J. (1992). Survey expectations and stochastic trends in modeling the employment-output equation. Oxford Bulletin of Economics and Statistics, 12(54), 579-589.

Roberts, J. M., \& Skoufias, E. (1997). The long-run demand for skilled and unskilled labor in Colombian manufacturing plants. The Review of Economics and Statistics, 79(2), 330-334. http://dx.doi.org/10.1162/003465397556700

Saudi Arabian Monetary Agency Annual Report (SAMA). Saudi Arabian Monetary Agency: Riyadh, Kingdom of Saudi Arabia, different years. Retrieved from http://www.sama.gov.sa

World Bank. World Bank indicator, different years. Retrieved from http://data.worldbank.org/indicator/

\section{Copyrights}

Copyright for this article is retained by the author(s), with first publication rights granted to the journal.

This is an open-access article distributed under the terms and conditions of the Creative Commons Attribution license (http://creativecommons.org/licenses/by/4.0/). 